\title{
The Rise and Demise of the Irish and Scottish Computer Hardware Industry
}

\author{
CHRIS VAN EGERAAT and DAVID JACOBSON
}

[Paper first received, June 2003; in final form, November 2003]

\begin{abstract}
This paper examines the dynamics of the computer hardware industry in Ireland and Scotland in a global context, from its inception in the late 1950s to the present. It provides a detailed account of plant openings and closures in both the system assembly and the component manufacturing segment. It describes the development of the computer hardware industry from mainframe assembly, through minicomputer assembly to microcomputer assembly and the shift of system assembly and component production activity to the Far East and Eastern Europe since the mid-1990s. The developments are analysed in terms of Schoenberger's (1997) model of concentrated deconcentration in the context of time-based-competition. It is shown that the model, with substantial qualification, fits the developments since the 1980s.
\end{abstract}

\section{Introduction}

The main location of computer hardware production in Europe has for decades been Scotland and Ireland and by the end of the 1990s both countries had developed a sizeable computer manufacturing industry. Together they manufactured around 70 per cent of branded PCs sold in Europe. The fortunes of the industry appear to be changing, as evidenced by recent job losses and plant closures. However, in both countries the sector has never been static. Rising or stable employment patterns over the last three decades conceal important changes in the structure of the sector. The focus of this article is on the dynamics of the sector in Ireland and Scotland in a global context, since its inception in the 1950s. This focus includes both the computer assembly and the computer component sectors.

The changing geography of computer production has been the subject of previous work, notably Angel and Engstrom (1995), Kraemer and Dedrick (1998) and Dedrick and Kraemer (2002). Much of this work focuses on the US computer industry and the growth of computer hardware production in East and South-East Asia. Relatively little work is done on related dynamics of the computer hardware industry in Europe.

Some of the data presented in this article were collected as part of a broader case study of the Irish and Scottish microcomputer hardware industry ${ }^{1}$ (Van Egeraat, 2002). This study involved semi-structured, face-to-face interviews with staff at the eleven branded computer

Chris van Egeraat, NUI Maynooth, Co. Kildare, Ireland. Tel: (+) 353-1-7083610. E-mail: cvane@eircom.net David Jacobson, DCUBS, Dublin City University. 
makers operating in Ireland and Scotland. A range of staff members was interviewed in three separate rounds during the period 1998-2002 - amongst others, materials managers, logistics managers and general managers. Other interviews were conducted with staff at a selection of component suppliers and industrial development agencies. Most of the data presented in this article were collected via an Internet-search of newspaper articles, corporate web-sites and annual reports.

The material provides an opportunity to explore the relevance of existing models or frameworks of international trade and investment. Elsewhere we showed that Vernon's product cycle model $(1966,1979)$ was of limited relevance to the dynamics of investments in the microcomputer hardware industry in Ireland and Scotland (Van Egeraat, 2003; however, see also Bradley, 2001). The activities of the production facilities in Ireland and Scotland do follow a clear sequence, from the production of mainframe computers, via minicomputers, to microcomputers. However, even during the first three decades following WW II, the period during which the explanatory power of Vernon's model is considered to be greatest, the dynamics of international investment in the computer industry diverged substantially from the model.

This paper explores the relevance of a different model - Schoenberger's (1997) model of concentrated deconcentration in the context of time-based-competition. Schoenberger presents some stimulating ideas as to the present drivers of industrial location and the investment strategies of multinational enterprises (MNEs). She argues that after the era of mass production, which ended with the economic crisis of the early 1970s, the world has entered a new era of time-based-competition (Stalk \& Hout, 1990). In this new era producers are facing a very different competitive environment characterised by highly differentiated demand and shorter product life cycles. The role of time in competition has changed drastically. The central focus is on reducing product development times and order-to-delivery cycles.

Schoenberger believes that this is changing the geographical configuration of the production networks of MNEs and the geography of production in general. The ties to the market have strongly increased for both the producers of final products and for their suppliers. Early detection of rapidly changing market needs and rapid market response are strongly dependent on face-to-face communication between partners which is facilitated by a presence in the market. Furthermore, speedy and successful product development and product introduction require the involvement of a wide range of functions such as $\mathrm{R} \& \mathrm{D}$, manufacturing, sales and marketing and logistics. The necessary face-to-face interaction is facilitated when all these functions are located near to each other. As part of the focus on compressing order-to-delivery cycles, efficient product flow and logistics, notably just-in-time logistics, are also believed to increase the ties to the market and buyer-supplier proximity.

The stronger ties between and within firms will drive an increasing geographic clustering of production. This tendency for geographical consolidation of production is enhanced by the MNEs' response to the general compression of product life cycles and the difficulty in predicting the precise rate of product introduction. Rather than shifting mature products to peripheral production locations along the lines of the product cycle theory, firms adopt flexible process technologies that allow for the co-production of a range of product generations.

At the same time the stronger ties between final-goods-producing plants and the end-consumers will lead to a certain level of deconcentration. In addition, the pull of appropriate factor costs is not entirely redundant. Overall, Schoenberger envisages a development towards a kind of "concentrated deconcentration organised around geographically coherent, multinational market regions" (1997, p. 73). The stylised version of this scenario involves the MNE, together with its most important suppliers, creating one rather tightly integrated production complex, including some technical and strategic functions, in each of the primary target 
market regions. The market regions include, North America, the EU, East Asia and Southeast Asia.

Within the individual market regions Schoenberger foresees that the various lead-firms will cluster together, exploiting the advantages of a common supply base, leading to the reconstitution of industrial heartlands such as the British Midlands through the Ruhr in North-western Europe. Apart from this high-wage heartland she sees the development of a new kind of semi-periphery. This new semi-periphery is different from the old one in the sense that it is located adjacent to the industrial heartland. New semi-peripheral regions need a well-developed infrastructure since the output of the plants must be able to flow smoothly to the respective industrial cores. The dominant linkages will be external, connecting individual plants with operations in the industrial heartland. The new semi-peripheral regions need to offer relatively low wages and flexible labour markets but at the same time literate and trainable labour forces as workers may operate quite advanced machinery. This new semi-periphery will attract the less qualified, more standardised, and more factor-cost sensitive parts of the production chain. The economies are likely to be truncated.

The following two sections describe the dynamics of the computer assembly and component manufacturing sub-sectors in Ireland and Scotland. Next, we analyse the industrial dynamics in terms of Schoenberger's model. We show that concentrated deconcentration fits the developments in the period since the 1980s - when time-based-competition is pervasivealthough with one important qualification. In the final section we draw conclusions for theory and industrial policy in Ireland and Scotland.

\section{Development of the Computer Industry in Ireland}

\subsection{System Assembly Plants in Ireland}

Ireland has been a relative latecomer as regards industrial development. After a protectionist period that lasted until 1958, the Irish government adopted a new economic and industrial development model based on outward-looking policies such as free trade, the encouragement of exports and inward foreign direct investment (O'Malley, 1989). In the 1970s, the Industrial Development Authority (IDA) set out with a focussed targeting strategy of searching out emerging growth sectors and their star companies (MacSharry \& White, 2000). One of the target sectors was electronics and computers and within this, the IDA focussed on a number of sub-sectors including, inter alia, minicomputers, computer peripherals and subassemblies (Hanna, 1984).

In 1971 one of the first major successes of the direct marketing approach was the decision by Digital Equipment Corporation, one of the pioneers in the minicomputer industry, to set up a large-scale minicomputer manufacturing plant in Ireland (Table 1 outlines the history of plant openings and closures by the main computer assemblers). Digital's presence had a strong demonstration effect, heavily influencing the decision of many major multinational computer hardware and software companies to locate in Ireland. In the latter half of the 1970s five other minicomputer companies - Prime, Nixdorf, Computer Automation, Concurrent and Wangset up assembly facilities in Ireland, while Amdahl started assembling mainframes. The companies were attracted by a 100 per cent tax exemption on export profits, access to the European market, relatively low wages and an educated labour force, although the demand for graduate engineers and technicians started to outpace supply (MacSharry \& White, 2000).

The success of the 1970s was interrupted by the economic crisis of the first half of the 1980s. Compounding the crisis was a shrinking market for minicomputers due to the increasing popularity of the personal computer (PC). As a result, most of the minicomputer assemblers that had been attracted in the late 1970s closed their Irish plants in the 1980s. 
812 Chris Van Egeraat and David Jacobson

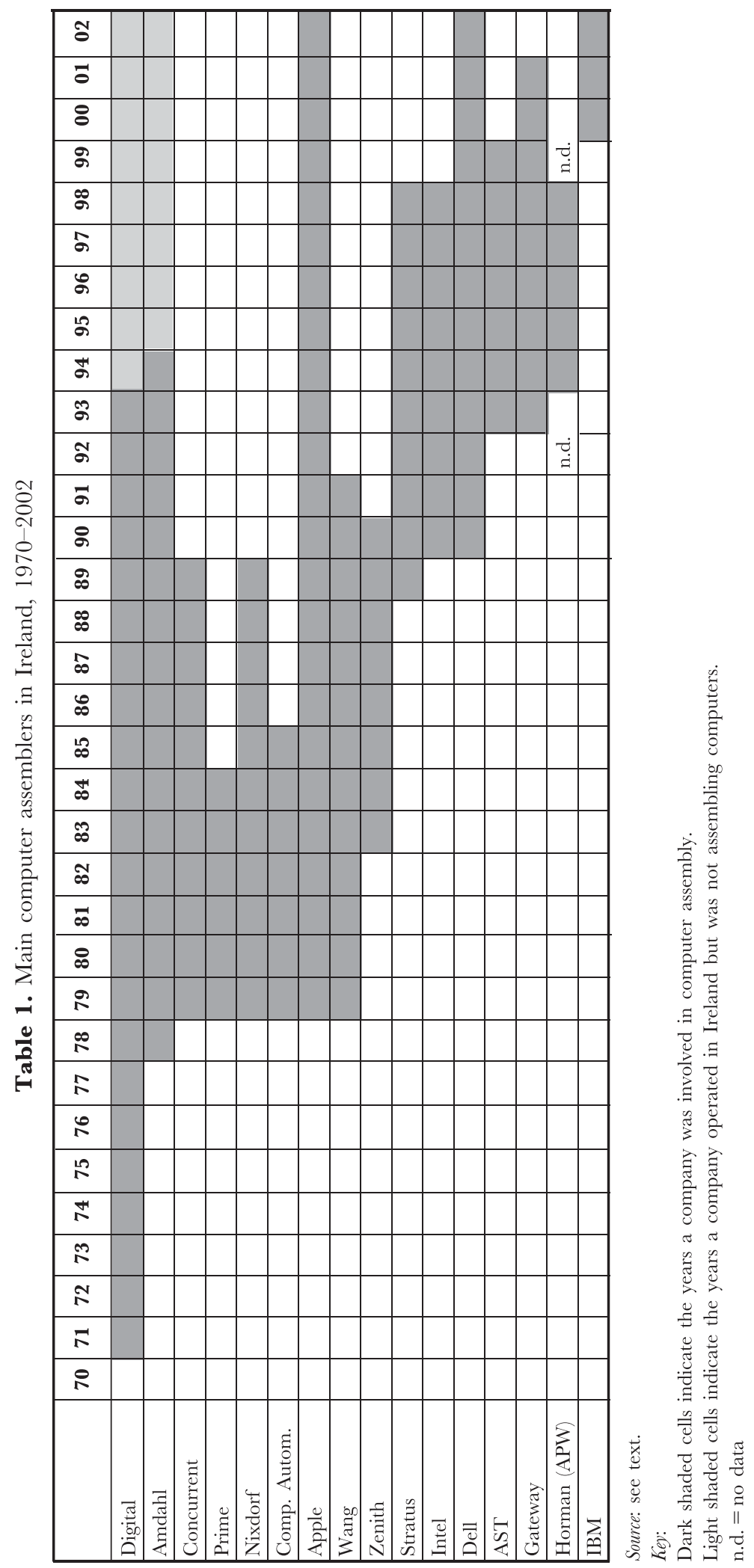


Table 2. Key growth indicators computer assembly sector in Ireland, 1980-1999*

\begin{tabular}{lcccc}
\hline Year & $\begin{array}{c}\text { Total } \\
\text { employment** }\end{array}$ & Sales $(\boldsymbol{£} \mathbf{b n}) * * *$ & Exports $(\boldsymbol{f} \mathbf{b n}) * * *$ & $\begin{array}{c}\text { Irish raw } \\
\text { materials as } \\
\text { percentage of } \\
\text { total*** }\end{array}$ \\
\hline 1985 & 3,082 & 1.7 & 1.7 & $5.1 \%$ \\
1990 & 3,426 & 2.3 & 2.2 & $11.1 \%$ \\
1995 & 4,752 & 3.1 & 3.0 & $27.0 \%$ \\
1998 & 6,719 & 4.4 & 4.1 & $28.0 \%$ \\
1999 & 6,569 & 6.7 & 6.4 & $27.6 \%$ \\
\hline
\end{tabular}

Notes:

*Data on the computer assembly companies that operated in Ireland over the last 25 years were extracted from the annual Irish Economy Expenditure (IEE) survey carried out by Forfas. Included were data on Digital, Concurrent, Prime, Stratus, Nixdorf, Computer Automation, Amdahl, Apple, Zenith, Wang, Dell, AST and Gateway. Data on Intel (ESSM) were excluded since it was not possible to separate data on this plant from data on the wider Intel operations in Ireland. The data should be treated with caution, since they have been grossed up from small samples. Data on individual years might not include all companies.

**Estimates for Intel ESSM included on the basis of employment growth of 200 per year from 1990 to a maximum of 1,500 in 1997.

***Excluding Intel ESSM.

Source: Irish Economy Expenditure Survey, Forfas.

In response, in the early 1980s IDA replaced minicomputers with microcomputers as a target sub-sector. The exemption on export profits was replaced by a ten per cent corporate tax rate and a brisk response by the Irish education system resulted in an increasing number of engineers/technicians (MacSharry \& White, 2000). The first PC assembler to arrive in Ireland was Apple in 1980. As the pioneer of the PC, Apple's investment decision had a major demonstration effect within the electronics industry. In 1983 Zenith followed with another PC assembly facility. Wang added microcomputer manufacturing lines to its existing facility in the mid-1980s. However, the crisis of the early 1980s meant that the real effect was not felt until the end of the decade. The real breakthrough came in 1989 with the decision of Intel to invest in a sophisticated microprocessor wafer manufacturing plant as well as a PC and motherboard assembly plant.

Like Apple and Digital in previous decades, Intel's presence attracted a large number of computer related companies that followed in the early 1990s. Among microcomputer assemblers, initially Wang and Zenith were out-competed and finally closed their Irish facilities, while Digital, which had started assembling workstations and PCs in Ireland, decided to consolidate its assembly operations in Scotland, resulting in the closure of the Irish assembly plants in 1993 (Digital kept a software development function in Ireland). However, these losses were more than offset by the investment of three new PC assemblers, Dell, Gateway and AST, while an indigenous subcontractor, Horman Electronics, diversified its activities with full system assembly for Apple.

During the second half of the 1990s, certain sub-sectors of the electronics industry in Ireland experienced increasing competition from lower cost production locations. Following a policy review in 1996, within its key target sub-sector 'computer systems', the IDA changed its focus to server manufacturing (Ryan, 1996).

In 1998, the Irish microcomputer assembly sector had reached its peak in employment terms (see Table 2). According to the Irish Economy Expenditure (IEE) survey, five microcomputer makers (Apple, Dell, Gateway, Intel ESSM and AST) and one contract electronic manufacturer (Horman Electronics), employed over 6,700 permanent staff. Our own inter- 
view data suggest that the microcomputer assemblers employed just under 10,000 permanent staff (full time equivalents) while at peak periods the head count could rise well above this figure $^{2}$. The computer assembly sector (excluding Intel ESSM) had sales of IR $£^{4}$.4bn, nearly all in exports. According to the IDA's own calculations, 33 per cent of PCs sold in Europe in 1999 were manufactured in Ireland (IDA promotional material quoted in Brennan, 2001). Our interview data show that the manufacturing activities of most companies were restricted to the final assembly and test of PCs and low-end servers. Intel ESSM and Apple also assembled motherboards, partly for internal use. Most operations included other functions, such as sales and technical support call centres (Dell, Gateway and AST), European logistics centres (Apple, Dell, Gateway and AST) or, in some cases, regional headquarters (Apple and Gateway). ${ }^{3}$

Between 1998 and 2002, the Irish microcomputer assembly sector experienced serious job-losses and plant closures due to both a competition induced shake-out of branded microcomputer makers and a shift of production activity to lower-wage economies. Intel ceased system assembly in Ireland and consolidated assembly activities in Malaysia, in Puerto Rico and, to some extent, in the USA. Apple shed 450 jobs when the production of I-Mac systems was outsourced and shifted - first to LG Electronics in Wales (The Sunday Business Post, 31-01-1999), subsequently to LG in the Far East (Interview Barry, Apple, April 2001) and finally to Foxconn in the Czech Republic (Pravo, 02-11-2000). Horman Electronics lost its system assembly contract with Apple. AST (Taylor, 1998) and Gateway (Smyth, 2001) were both out-competed and closed their European operations. Thus, of the five microcomputer companies in 1998, by 2002 only Dell and Apple were still assembling microcomputers, and Apple's system assembly operation was seriously downsized (see Figures 1 and 2).

\subsection{Component Plants in Ireland}

The computer component and peripheral sector in Ireland was slow to develop. In the second half of the 1970s less than a dozen foreign companies produced a range of products such as memory, printers, components for disc drives, cables/interconnect material and floppy drives (see Appendix, Table Al). Digital had opened a plant to produce network components for in-house use. Most cases involved relatively unsophisticated operations. In addition, a handful of existing or newly established indigenous companies started to capture a small part of the market for enclosures and printed matter.

The economic crisis of the early 1980s did not help things. Some of the component manufacturers that had been attracted during the 1970s closed their Irish plants, e.g. Mostek and Centronics (MacSharry \& White, 2000). The period saw very few new investments. One of the main developments was Western Digital's decision to open an automated controller circuit board manufacturing facility. The Keyboard Company set up a facility to supply Apple, but this plant was taken over by Apple and closed soon after in 1985. According to the Irish Economy Expenditure (IEE) survey, during the early 1980s computer assemblers sourced only five to six per cent of their material inputs from suppliers located in Ireland (see Table 2).

As part of its policy rethink of the mid-1980s, in an effort to increase the attractiveness of Ireland for foreign MNEs, and at the same time increase their local embeddedness and spend in the Irish economy, the IDA aimed to upgrade the local supply structure. One way was through the attraction of foreign component suppliers. Additionally, the National Linkage Programme (NLP) was set up in 1985 with the objective of significantly increasing the proportion of sub-supply materials purchased by MNEs from indigenous Irish companies or smaller foreign companies located in Ireland.

The strategy did not meet with instant success, however. During the second half of the 


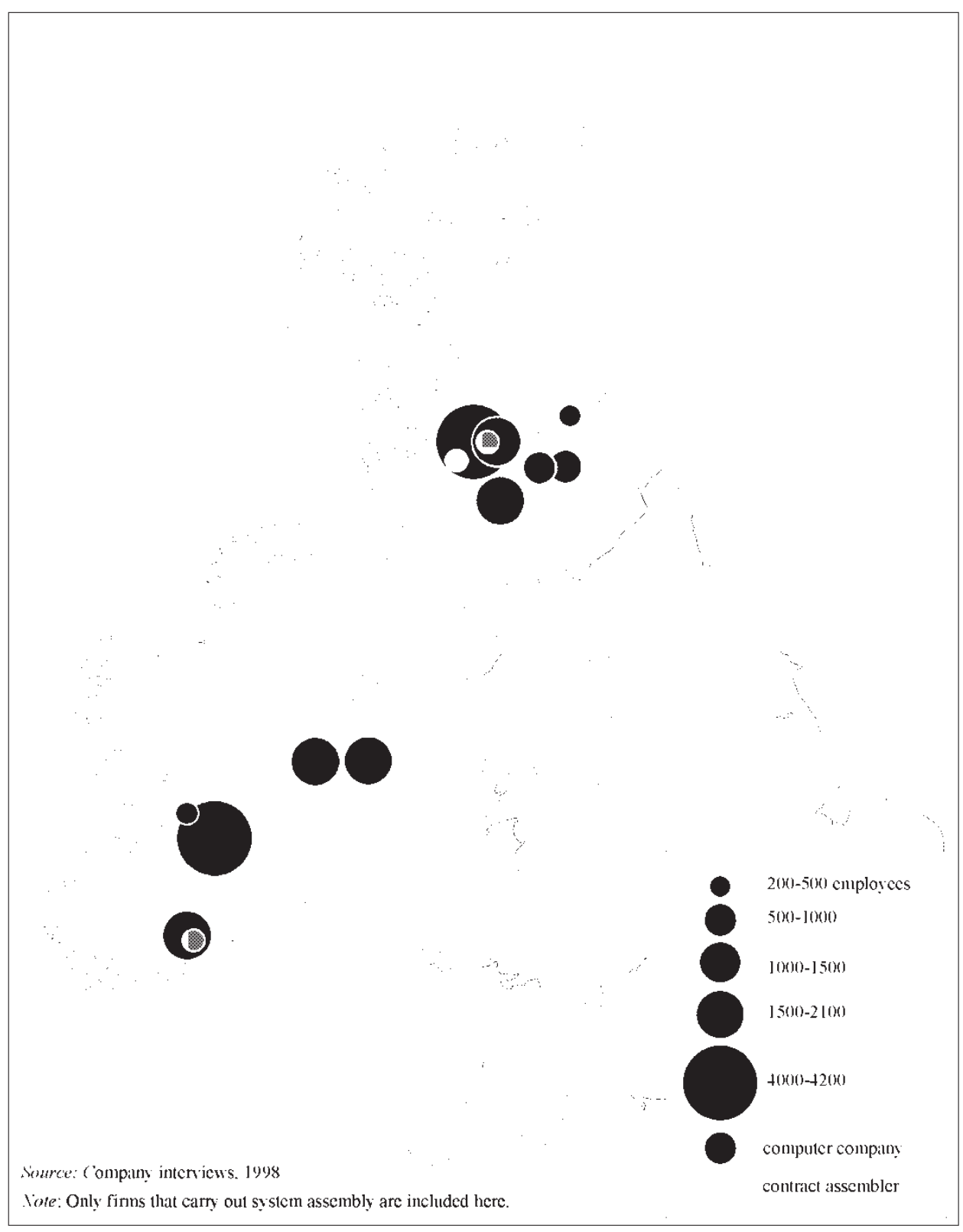

Figure 1. Microcomputer Assembly: Ireland and Scotland, 1998.

1980s, a handful of companies started assembling keyboards, mice and cables for the expanding local and European markets. Apart from these low-tech projects, Apple started automated motherboard assembly for in-house use. According to the IEE survey data, the percentage of total components sourced from suppliers in Ireland remained around six per cent (not shown in Table 2).

More substantial progress was made in the early 1990s. Existing and newly established indigenous companies captured an increasing share of the market for enclosures, cables, printed matter, packaging and supply-chain management services. Furthermore, the IDA was 


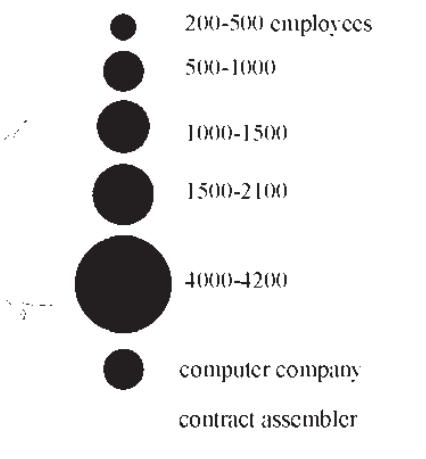

Figure 2. Microcomputer Assembly: Ireland and Scotland, 2003

attracting an increasing number of foreign companies investing in medium-tech manufacturing facilities for the production of motherboards, network cards and hard disc drives. One of the most significant developments was Intel's decision to invest in a high-tech microprocessor wafer fabrication plant. By 1995 computer assemblers sourced 27 per cent of their material inputs in Ireland and the manager of the NLP predicted that the Irish content of PCs produced in Ireland would rise to 40 per cent (Casey, 1995).

However, during the second half of the 1990s the basis for this expectation was undermined. Ireland experienced increasing competition from low-wage economies, particularly in 
the Far East. In 1996 the IDA started to actively discourage large companies from locating certain manufacturing operations in Ireland where the main attraction was a lower cost base (Carey, 1996). In its 1996 policy review the IDA decided to drop the sub-sector 'peripherals and media' as a key target sector. New sub-sectors to be targeted included software development, contract manufacturing and computer networking/data-communication (Ryan, 1996).

Ireland continued to attract a number of high-tech, high output, manufacturing and service projects, notably successive Intel wafer fabrication plants. Furthermore, a substantial number of foreign contract electronics manufacturers $(\mathrm{CEM})$ continued to invest in enclosure manufacturing and subassembly plants. In most cases this involved the take-over of existing indigenous companies and plants. However, between 1995 and 1998, a large number of lowand medium-tech component manufacturers closed their Irish plants and shifted production abroad, notably to the Far East (see Appendix, Table A2).

Four keyboard and mice manufacturing plants closed when production was relocated to the Far East (Carey, 1996; Hogan, 1998b; O'Kane, 1995, 1996; The Irish Independent, 10-01-98). Plastic component manufacturer Acco closed due to competition from Asia (Clifford, 1998). Seagate closed its hard disk drive assembly facility and consolidated production in the Far East. Disk drive component supplier Applied Magnetics closed. Both Intel and Apple shifted their labour intensive motherboard assembly activities from Ireland to the Far East (Hogan, 1998a). Intel also ceased the cartridge assembly activities that it had carried out in Ireland since 1998 and consolidated activities in the Philippines and Puerto Rico.

The growth in local sourcing figures had levelled off since the mid-1990s. According to the IEE survey data, by 1999 the microcomputer assemblers sourced 28 per cent of their material inputs in Ireland, up one percentage point from the 1995 figure. Our own data obtained during the interviews with the microcomputer assemblers in Ireland suggest that the IEE figures strongly overestimate local sourcing in the industry. ${ }^{4}$ Four branded microcomputer makers (excluding Intel) provided an estimate of expenditure on locally manufactured components. In the period 1998 to 1999, on average, ten per cent (of the value) of the parts and components sourced by these assemblers were manufactured in Ireland (ranging from seven to twelve per cent).

Our detailed investigation of the supply networks of the five microcomputer assemblers in Ireland showed that the supply network in Ireland included 47 (mainly foreign) companies operating 57 component plants. ${ }^{5}$ However, the vast majority of components and parts were imported, notably from the Far East and, to a lesser extent, Britain and the USA. The only items characterised by significant sourcing in Ireland were: enclosures, network cards, media, accessory kits, cables/interconnect, packaging material and keyboard localisation. Even then, the majority of network cards, cables, as well as significant parts of enclosure supplies, were manufactured abroad, notably in the Far East. Component plants in Britain played some role in the supply of motherboards/backpanels and, to a lesser extent, monitors but, again, the majority of these items were imported from the Far East.

The shift of component plants to the Far East continued at the start of the new millennium. MKIR Panasonic closed Europe's last remaining hard disk drive manufacturing plant in Dundalk under severe price competition from manufacturers in Asia (Keogh, 2000). Volex transferred the main part of its cable assembly activities to Eastern Europe and Asia (Turnbull, 2002). However, the problems related to competition from low wage economies were now compounded by a drop in business from local customers such as Gateway, Apple and Dell - in turn the result of the downturn in the global computer industry and the shift of system assembly activity to lower cost regions. As a result, in the period 1999-2003, six enclosure manufacturing and subassembly plants closed their doors while other plants suffered job losses. 


\section{Development of the Computer Industry in Scotland}

\subsection{System Assembly Plants in Scotland}

In Scotland, the electronics industry was targeted by the Scottish Development Authority (SDA) from an early stage and by the end of the 1970s the data processing industry was amongst the three most important 'areas of attack' as regards inward investment (LIS, 1983; SDA, 1979). The main marketing tools in attracting FDI to Scotland, included access to the UK and, since 1973, the European market, relatively low wage rates and financial and fiscal incentives (McCalman, 1988) - although the fiscal incentives were not nearly as attractive as those in Ireland.

The roots of the computer industry in Scotland go back to the late 1940s and early 1950s (see Table 3 for an outline of the history of the computer assembly activity). In this post-war period Scotland attracted a substantial number of large USA based companies involved in the manufacture of electromechanical products, such as IBM, NCR, Timex, Burroughs and Honeywell. Most of the plants later responded to changing markets and diversified into electronics products, with varying degrees of success. IBM assembled its first mainframe computer in Scotland in 1959. Honeywell started mainframe production at its Newhouse facility in 1964 and Burroughs followed in 1970. NCR only diversified into computer assembly in the 1980s, although the NCR plants in Scotland had been involved in computer component production from the 1950s. (Interview Adamson, NCR, December 2001).

With the rise of the minicomputer during the 1970s, the Scottish computer industry received a further impetus from Digital's decision in 1976 to expand its European production capability with a system assembly plant in Ayr. Some of the established mainframe plants got involved in the manufacture of minicomputers as well.

The rise of the market for PCs and workstations during the 1980s led to a new wave of restructuring involving major downsizings and job losses as well as new investments. Some of the players in the mainframe and minicomputer market were out-competed leading to rationalisations and the closure of some production facilities. Honeywell stopped producing mainframe and business computers in the second half of the 1980s. The global computer division was sold to Company Bull which continued the production of Honeywell-Bull branded mainframes and minicomputers in rented space at the Newhouse facility during the rest of the 1980s. Burroughs closed its minicomputer assembly plant after rationalisation following the merger between Burroughs and Sperry Univac to form Unisys.

In 1983 IBM dedicated a large part of its manufacturing space to the production of PCs, making the Scottish operations the centre for personal systems in Europe- a major milestone for the development of the PC industry in Scotland (IBM, 1991). Digital started assembling workstations in its existing facility in Ayr. New arrivals during the 1980s included PC assemblers such as Wang, Compaq and Birmingham based Apricot, as well as two USA based workstation assemblers, Apollo and Sun. The Scottish success in attracting three of the main workstation producers might be partly related to the weight of public purchases in this sector. Allegedly, the latter were made conditional on the location of new investment projects within the UK (MacSharry \& White, 2000). The NCR facilities in Dundee increasingly focussed on ATM systems.

Other existing electronics plants such as Timex and GEC/GPT moved for short periods into PC manufacturing as subcontractors (Green, 1992). The only indigenous entrant was Mimtec in Livingston. Mimtec only started subcontract work for IBM in 1984 but by the end of the decade had already shipped more PCs than IBM's Greenock operation (Bain, 1997). Competition and consolidation in the global computer industry meant that Apollo and Wang, two of the branded computer makers that had arrived in the 1980s had gone again by the end of the decade (Clarke \& Beany, 1993). 


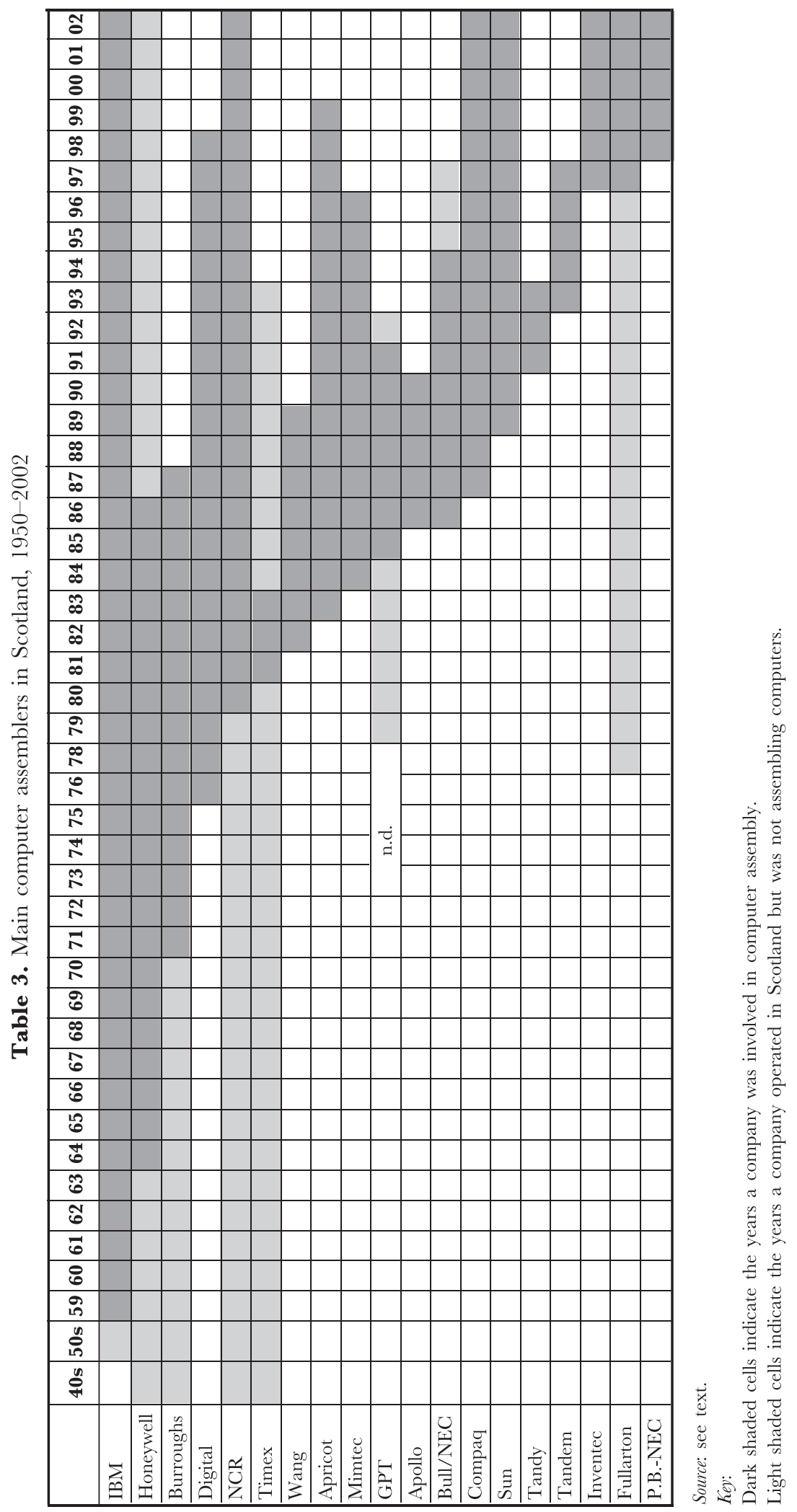


The period until 1998 saw a further expansion of computer assembly activity, partly related to the outsourcing strategies of existing branded computer plants. USA based Tandy opened a PC assembly facility in 1991. But this was closed again two years later when the company was taken over by AST. Mimtec expanded with a new facility in Gourock (Dean, 1993) before being taken over by indigenous Fullarton. Tandem, also from the USA, started producing large fault tolerant systems in the facility vacated by Wang, and Digital opened a dedicated PG assembly plant in Irvine. The Bull-NEG venture moved into the vacated Apollo facility in Livingston to produce minicomputers and PCs, but stopped assembling computers three years later, concentrating instead on system configuration and software development. The plant was subsequently occupied by Packard Bell-NEC, which started assembling PCs. Taiwanese Inventech invested in a new facility to assemble low-end systems for Compaq.

As in Ireland, the microcomputer assembly sector in Scotland had reached its peak around 1998. Six of the main global branded microcomputer makers, IBM, Compaq, Digital, Packard Bell-NEC, Sun and Apricot-Mitsubishi operated system assembly plants in Scotland while two companies, Fullarton Computers and Inventec were involved in system assembly on a subcontracting basis. Compared to Ireland, to some extent the companies were manufacturing higher-end products. Four companies were assembling only low-end PC and server models but four other companies were assembling higher-end servers, workstations, storage systems and larger fault tolerant computers as well. IBM, Compaq, Digital and Apricot were assembling limited amounts of server boards on site. Some companies housed non-manufacturing functions at their Scottish facilities, including call centres for technical support and central order desks, system development groups (IBM and Digital). Sun located its regional headquarters at its Scottish facility. According to the interview data the eight microcomputer companies together employed in excess of 9,500 permanent staff (the non-system assembly activities of Fullarton not included) while at peak periods the head count could rise well above this figure. According to the calculations of the SDA, in 1997 Scotland produced almost 37 per cent of the branded PCs sold in Europe, 68 per cent of electronic notebooks, 60 per cent of Europe's workstations and 16 per cent of its computer peripherals (Carding, 1997).

As in Ireland, the period since 1998 has been characterised by serious job-losses and plant closures. Here too, the underlying causes include a global downturn in the market for computer systems, competition-induced liquidation and merger activity and increasing competition from lower-wage economies.

Apricot-Mitsubishi pulled out of PC manufacturing leading to the closure of the Glenrothes plant in 1999 (Duncan, 1999). Compaq acquired Digital and Tandem and in the 1998 restructuring process Digital's PC plant and Tandem's high-end server facility were closed and production was consolidated at Compaq's facility in Erskine (Urquhart, 1998). Some 860 jobs were lost at Compaq's Erskine facility in 2001 when nearly half of the assembly activity was outsourced to a company in the Czech Republic (Murray, 2001). The following year Compaq's Ayr plant was sold to Jabil in a server board outsourcing deal that included the transfer of 240 staff. Ayr's server assembly operations involving 430 workers moved to Erskine. In the same year the company merged with Hewlett-Packard and another 700 jobs were lost when more assembly activity was moved to Poland, leaving 900 (mostly non-manufacturing) jobs in Erskine (Denholm, 2002). Shortly afterwards 600 jobs were cut at the microcomputer assembly plants of Inventec, Compaq's local outsourcing partner, leaving a small server assembling operation (Dey, 2002a).

IBM had been restructuring its operations in Scotland away from manufacturing to customer support call centres and other service activities since 1998. In 2003 it announced an outsourcing arrangement with Sanmina-SCI that included the sale of most of its assembly operations at the Greenock campus and a transfer of 640 permanent employees and 700 contract workers to its global partner. Very few of the remaining 3,000 IBM employees were 
involved in manufacturing (Young, 2003). In a related move, Fullarton closed its Gourock facility with the loss of 500 workers when it lost the contract to assemble IBM PCs. Competition from lower cost operations in Eastern Europe was cited as the reason (Doherty, 2003). The only positive news in this period relates to Sun Microsystems. The company had already outsourced most low-end assembly operations before 1998 and in 2002 actually took on 200 workers to manufacture high-end servers (Murray, 2002)

\subsection{Component Plants in Scotland}

The computer component sector was relatively small prior to the $1980 \mathrm{~s}$, although some of the system assemblers produced components on-site (see Appendix, Table A3). IBM manufactured keyboards, monitors and printers (IBM, 1991). Burroughs produced hard disk drives and Honeywell even operated a sheet metal shop until 1974. Two indigenous companies were involved in cable assembly and metal stamping (Young, 2001; Hall, 1993). More sophisticated production of integrated circuits was carried out by Prestick Circuit, a company that would become an important supplier to IBM.

Data on the local linkages of computer assemblers as such do not exist but there are data on the electronics industry, that by the end of the 1970s was dominated by the computer assembly industry (McCalman, 1988). An SDA study of the electronics industry in Scotland showed that in 1979 packaging and printed circuit boards were the only supplies sourced primarily in Scotland. The sourcing of metal products was divided equally between Scotland and England (SDA, 1979). Data from the Industry Department for Scotland show that by 1979, electronics companies sourced only ten per cent of their commodity purchases in Scotland (Turok, 1997).

In 1979 the SDA responded with a strategy to strengthen the supplier base, either through the stimulation of indigenous enterprise or inward investment (SDA, 1979). The strategy did have some success. Indigenous Rodime and USA owned Conner Peripherals opened disk drives manufacturing plants. Domain Power, another indigenous start-up, produced power supplies while USA owned Eeco opened a keyboard manufacturing facility. Slightly earlier than in Ireland, Scotland attracted a number of circuit board assemblers while IBM and Digital expanded with on-site circuit board assembly lines. The local operations of Digital became even more integrated when it started producing and packaging Alpha processors. New indigenous sheet metal companies joined the component sector as enclosure suppliers while other indigenous companies started as low-tech general subcontractors, initially to IBM.

The expansion of the supplier base had only a limited impact on the proportion of material inputs that the system assemblers sourced in Scotland. Surveys of electronics companies carried out in 1984 (McCalman, 1988), 1986, 1988, 1990 and 1991 (Turok, 1993) all come up with a figure between twelve and fifteen per cent (by value), although the figure for computer companies was probably slightly higher - the 1984 survey by McCalman showed that eight computer assemblers sourced 21 per cent of their inputs (excluding purchases from parent organisations) in Scotland. A survey of thirteen of the largest foreign electronics companies in Scotland (including all the major computer assemblers) carried out in 1991, showed that the highest levels of local sourcing were found in low-tech component categories such as keyboards, plastics, cables, metal, packaging and printed material. More sophisticated, higher value, components were almost all imported (Turok, 1993).

Some of the component plants that had opened in the 1980s closed again in the first half of the 1990s (see Appendix, Table A4). Eeco, Rodime and Conner Peripherals were all out-competed. Some system assemblers closed selected component manufacturing lines in their Scottish plants. IBM outsourced keyboard and monitor assembly while Digital shifted 
production of Alpha processors to the USA (Hunter, 1995). The processor packaging activities at Digital's Ayr facility also ceased.

At the same time, up to 1998, Scottish Enterprise was relatively successful in attracting new component plants. Three USA based contract electronic manufacturers invested in new computer circuit board plants, while Apricot, Compaq and Sun Microsystems all added circuit board assembly to their system assembly operations. Four foreign metal and plastic manufacturers joined with new enclosure plants. Korean Lite-on invested in a new monitor plant. This plant received inputs from Chunghwa which had invested in a picture tube plant in Scotland. Seagate started hard-disk drive configuration in the old Conner Peripherals plant. Other foreign companies opened facilities for the production of power supplies and cable assembly.

As in the 1980s, the new investments do not appear to have had a substantial impact on the level of production linkages of the system assemblers. As a proportion of total purchases (excluding electronic components, inter-company trading and services), local sourcing by the sixteen largest foreign owned electronics companies (including all the main computer assemblers) fell from 27 per cent in 1992 to 21 per cent in 1995 (Turok, 1997).

Our own data obtained during the interviews with the six branded microcomputer makers in Scotland show that in the period 1998-1999, an average of seven per cent of the value of material inputs sourced by the computer assemblers was manufactured in Scotland (ranging from two to nine per $\left.\operatorname{cent}^{6}\right) .^{7}$ The local supply networks of the six computer assemblers included 49 (mainly foreign owned) companies operating 51 plants. The detailed picture is similar to that in Ireland. The main difference with the situation in Ireland was that the system assemblers in Scotland sourced a somewhat greater proportion of their motherboard requirements locally, although here too, the majority of motherboards were imported, notably from the Far East.

Since 1998 the Scottish computer component sector has been hit by a series of job-losses and plant closures, the consequence of a downturn in the demand from computer assemblers and increasing competition from low-wage economies. Two monitor assemblers closed their plants and production was shifted to Taiwan where monitors could be made more cheaply (MacKenna, 1998; James, 1998). Chungwha, which had been supplying one of these plants with picture tubes, closed its plant and moved production to China, partly under pressure of rising production costs in Scotland (Dey, 2002b). Compaq shifted its motherboard assembly activities to Singapore (Walko, 1998). Apricot outsourced its motherboard assembly activities to MSL in Ireland while Sun outsourced these activities to CEMs in Scotland and England. IBM outsourced server board assembly activities to Solectron that set up a new plant in Scotland but within less than two years this plant closed as well. Sanmina-SCI closed its Irvine assembly plant and shifted production to Hungary and Ireland (Daily Record, 21-08-2002). Amp, Amphenol and Techdyne all closed their cable assembly facilities in Scotland. Seagate closed its disk configuration facility. Finally, Foxteq closed its Scottish enclosure manufacturing facility after its main local customer, Compaq, shifted a large part of its assembly activity to the Czech Republic (Woodcock, 2001; Dow, 2002).

\section{Relevance of the Concentrated Deconcentration Model}

To what extent do the dynamics of the computer hardware industry in Ireland and Scotland fit Schoenberger's model of concentrated deconcentration in the context of time-based competition? The model was never supposed to pertain to the period before the economic crisis of the 1970s and we have no data on the extent to which computer companies had already adopted elements of time-based-competition in this period. However, data on the 
manufacturing activities of individual companies do suggest that elements of the model of concentrated deconcentration were already taking shape.

Some of the computer assembly plants were manufacturing for the wider European market while sister plants in the USA serviced the American market. In addition, the plants in Ireland and Scotland were not necessarily producing old product models, as would be suggestive of Vernon's product life cycle model. Rather, new product technologies were introduced virtually simultaneously in the American and European plants. In 1964 IBM's Scottish plant started production of the IBM 360 for the European market, the same year the product was launched in the US market. The following year, Greenock started assembly of the IBM 1130, again simultaneous with the launch in the USA. Both products incorporated the latest developments in computer technology (IBM, 1991). Similarly, among the first products assembled at Digital's plant in Galway in 1971 was the PDP 11/20 (Realised Vision, 2003). This product had been launched in the US market only one year earlier.

According to Schoenberger, the era of time-based-competition and concentrated deconcentration was in full swing in the 1980s and continued in the 1990s. This is the period of microcomputer production in Ireland and Scotland.

A detailed analysis of the elements of the value chain of eleven microcomputer assemblers in Ireland and Scotland showed that the microcomputer industry had many characteristics of textbook time-based-competition (Van Egeraat, 2002). Companies generally offered a wide variety of computer systems, to a great extent customised for individual customers. Minimisation of time and inventory levels figured as very important goals in the development, manufacturing, supply and distribution strategies of all companies. Product development/introduction time and the rate of new product introduction were important aspects of the strategies of nearly all the focal companies.

The requirements of time-based-competition did lead to a geographical configuration that had much in common with Schoenberger's concept of concentrated deconcentration. Thus, the new investments by microcomputer makers in Scotland and Ireland during the 1980s and 1990s generally took place in the context of a rapid globalisation strategy. In 1998 all but two of the eleven assemblers with operations in Ireland or Scotland had at least one microcomputer assembly facility in each of the Triad market regions: North-America; Europe, Middle East and Africa; and East/South-East Asia. Apart from this, four companies operated assembly plants in the emerging South-American market region (see Figure 3). All plants were manufacturing their company's entire range of microcomputers for the broad regions in which they operated although there was some intra-company specialisation among plants in the USA. Furthermore, because of the limited scale of demand, in some cases the most advanced servers were manufactured in the USA only.

In line with the model of concentrated deconcentration, apart from assembly plants, the European operations typically included a range of other functions such as sales and marketing, customer service, technical support and regional headquarters, although not necessarily located in Ireland/Scotland. European operations generally did not include substantial local-for-local R\&D groups, a reflection of the fact that companies were offering basically global products. Most microcomputer companies had concentrated their microcomputer development facilities in their home country.

One could argue that during the 1980s and early 1990s Ireland and Scotland functioned as the 'new semi-periphery' of Europe. Unit labour costs were below the levels in Europe's industrial heartland (Oulton, 1993). Furthermore, high unemployment in combination with labour market policies had fashioned a highly flexible labour force. At the same time, the presence of a critical mass of electronics companies and continued investment in education meant that both countries offered an increasingly skilled and trainable workforce. These conditions initially attracted the less qualified, more standardised and more factor-cost 


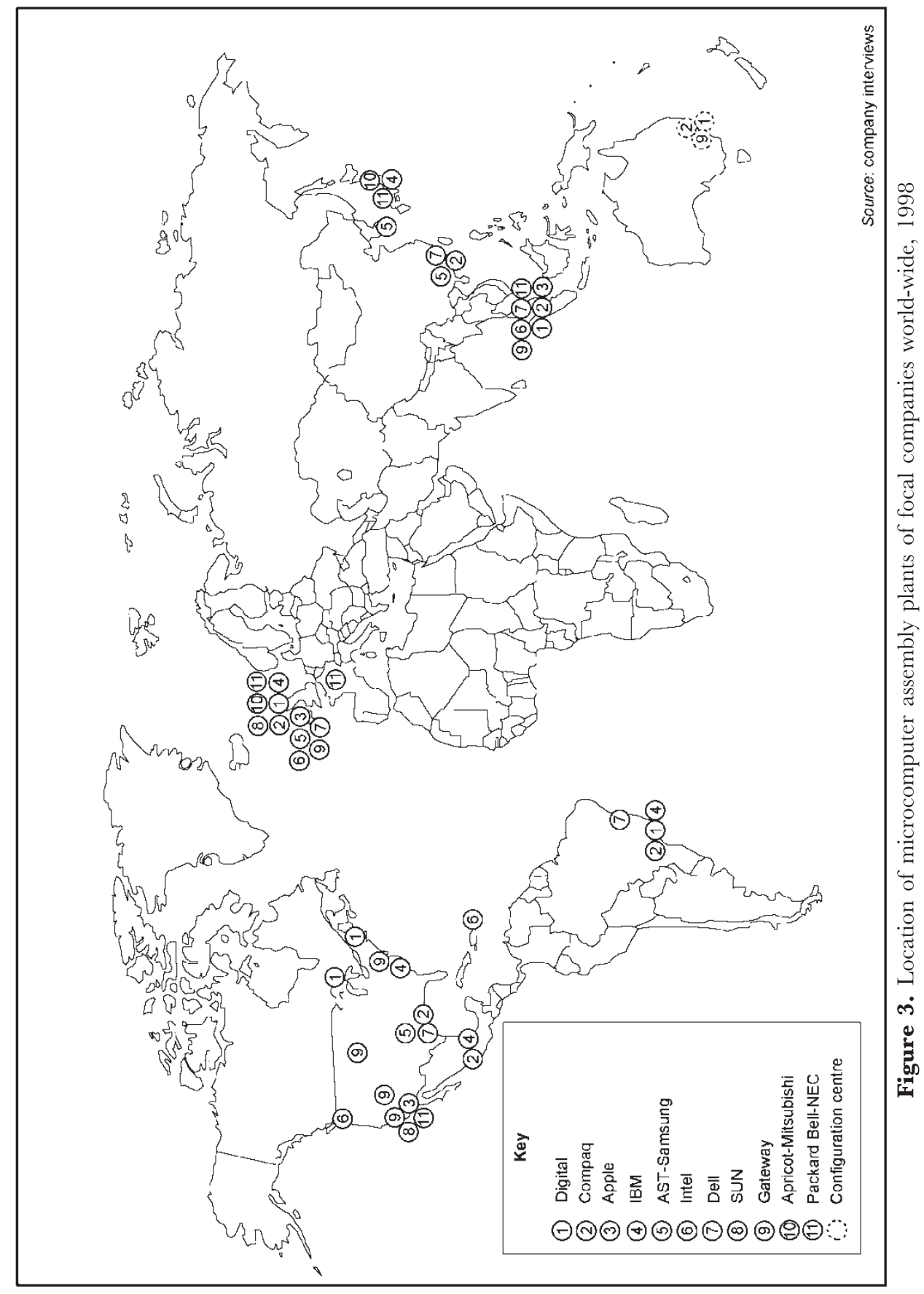


sensitive parts of the production chain, which in the case of the microcomputer industry included the system assembly plants of the lead firms. Thus, the interviews with the microcomputer companies showed that, along with fiscal and financial incentives, the flexibility of the labour force and relatively low labour costs were the principal factors in the decision to locate/expand European assembly operations in Ireland or Scotland (Van Egeraat, 2002). European headquarters and sales and marketing headquarters of most companies were located in European core regions. ${ }^{8}$

The situation started to change during the second half of the 1990s. Rising wage rates, in combination with the opening up of new low-wage regions in the Far East and Eastern Europe and the exchange rate effect of the Asian crisis, resulted in increased competition for Ireland and Scotland as low-cost production locations. For system assembly operations, competition from the Far East was not the biggest threat. Supplying build-to-order, often customised, relatively valuable systems with short order lead times from locations in the Far East would have to involve air-freight. This was simply not an option given the bulky nature of the product involved. However, the opening up of Eastern Europe created new production locations, offering low wages and a relatively skilled labour force, a short distance from the main EU market, and shortly to be within the EU. A number of countries in Eastern Europe were offering new production locations in Europe's new semi-periphery while, to an extent, Ireland and Scotland were joining the European core. As discussed, much assembly activity has recently been shifting to Eastern Europe. It is this development, in combination with the global downturn in the computer industry, that has been largely responsible for the closure of computer assembly facilities in Ireland and Scotland since 1998.

The main deviation from the model of concentrated deconcentration concerns the local/regional supplier base of the computer assemblers. The model incorporates the idea of final goods producers attempting to create integrated production complexes together with their most important component suppliers. As discussed, although in the first half of the 1990s the computer assemblers were starting to source more of their material inputs locally, local and regional suppliers never accounted for a large share of total material inputs. The vast majority of material inputs were imported, notably from the Far East.

Schoenberger suggests that buyer-supplier proximity will be driven by a need to compress order-to-delivery cycles and the need for face-to-face communication between partners. These drivers can be translated into a need for logistical efficiency and a need for efficient technical information exchange. The relevance of these ideas to the microcomputer hardware industry was investigated during the interviews with the eleven assemblers in Ireland and Scotland (Van Egeraat, 2002). It was found that efficient technical information exchange was a relatively weak driver for buyer-supplier plant proximity. Technical information exchange could generally be efficiently handled by a combination of locally based representatives of the suppliers, frequent long distant travel by engineers and the short-term out-stationing of engineers; it did not require the co-location of integrated supplier operations.

As to logistical efficiency, supplier location and linkage distance are the outcome of a complex trade-off among many factors - amongst others, the value of components, the weight of the components, the labour intensity of component production and regional differences in factor costs, notably labour costs. It was shown that, compared to the situation under traditional logistics management systems, the modern comprehensive logistics management principles that underlie time-based-competition and JIT supply do involve a stronger push towards buyer-supplier proximity. However, this does not mean that the new principles necessarily lead to buyer-supplier proximity. Regional differences in labour costs could still act as a powerful force against a reduction in the linkage distance. During the 1980s and early 1990s Ireland and Scotland were indeed attracting plants producing a range of components. 
However, both countries were always competing with lower-cost manufacturing regions in the Far East.

In the second half of the 1990s, rising labour costs in Ireland and Scotland in combination with the opening up of new low-cost production regions such as China and the effect of the Asian financial crisis on exchange rates meant that the outcome of the complex trade-off changed. Production of many components was shifting to the Far East. Component production activities that remained in Ireland and Scotland included bulky components, notably enclosures and items characterised by a relatively high variety of options such as accessory kits and the final configuration of keyboards. As discussed, recently Ireland and Scotland have been experiencing plant closures and job losses in these areas as well. These particular closures are not the result of rising competition from the Far East, however. The main cause here was the shrinking market for components due to the reduction of computer assembly activity in Ireland and Scotland. Some plants followed their customers to Eastern Europe while other plants were simply closed down.

\section{Conclusion}

This paper described the dynamics of the computer hardware sector in Ireland and Scotland in a global context. After its inception in the late 1950s the sector grew into one of the largest manufacturing sectors in Ireland and Scotland in the late 1990s. Since the late 1990s the hardware sector in both countries has experienced serious job-losses and plant closures. Structural changes in the computer sector have always been accompanied by employment losses and plant closures in certain sub-sectors and new investments in others. However, these changes generally had no significant impact on the position of Ireland and Scotland as locations for computer hardware production. Developments since the late 1990s appear to signal a more radical change in the prospects of computer hardware manufacturing in Ireland and Scotland.

The developments were analysed in terms of Schoenberger's model of concentrated deconcentration. Although the model was never supposed to pertain to the period before the economic crisis of the 1970s, elements of it were already taking shape in the 1960s and early 1970 s, with at least some computer companies operating similar manufacturing plants in at least two of the three main market regions of the world.

The model fits many of the developments in the 1980s and 1990s, the period of microcomputer production in Ireland and Scotland. Microcomputer assembly plants in Ireland and Scotland were part of regional operations that included manufacturing, technical support, sales and marketing and strategic functions. Nearly all companies had similar operations in the two other Triad regions. At least during the 1980s and early 1990s, Ireland and Scotland operated as the new semi-periphery of Europe, attracting the less qualified, more factor-cost sensitive parts of the production chain, including the system assembly plants. Regional headquarter and marketing functions were still located mainly in the European core regions. During the second half of the 1990s, rising wage rates meant that Ireland and Scotland no longer qualified as members of Europe's new semi-periphery while a number of Eastern European economies joined the semi-periphery. As a result, microcomputer assembly activity is shifting to Eastern Europe.

The main deviation from the model was that the vast majority of suppliers were not located locally or regionally, but in the Far East. The findings suggest that the two proximity drivers identified by Schoenberger, the need for efficient information exchange and the need to compress order-to-delivery cycles or logistical efficiency, do not necessarily lead to buyersupplier proximity. The modern logistics management principles that underlie time-basedcompetition have increased the forces working towards proximity. However, the geographical 
configuration of production networks, remains the outcome of a complex trade-off among many factors, including 'traditional' factors such as the volume and weight of the product and regional differences in labour costs. This means that in industries like the microcomputer industry, many small, light weight and labour intensive components will continue to be imported from suppliers located in low wage regions at great distances.

Overall, Schoenberger's model of concentrated deconcentration appears to capture the main forces and broad tendencies in the geography of production in the post-Fordist era. The ties to the market have certainly increased and to an extent this has led to the Triadisation of production. However, although mentioned by Schoenberger (1997, p.55, 73), her model underestimates the continuing role of labour costs, and the fact that the spatial outcome of the increased lure of the market will strongly depend on a range of physical characteristics of products. Large segments of manufacturing industry will still be organised on a spatially extensive scale. In addition, companies are able to address the increased importance of market access in other ways than through establishing a local production unit, e.g. through the use of locally based representatives and agents, frequent long-distance travel, the out-stationing of engineers and the operation of logistics hubs. Finally, the model does not address the possibility of industrial and economic development of individual production locations - leading to the establishment of new semi-peripheral locations and the upgrading of existing semi-peripheral locations in the direction of the industrial heartland - and an associated spatial shift of selected production activities.

These issues call for an adaptation or expansion of Schoenberger's model-perhaps integrating the ideas coming out of the global commodity chains (Gereffi \& Korzeniewicz, 1994; Gereffi 1999) and global production networks literature (Dicken et al., 2001; Henderson et al., 2002; Yeung et al., 2001). The latter approach specifically acknowledges that production networks of different industries are organised in different ways and incorporates the concept of the multi-scalar nature of production networks - the idea that production networks can simultaneously be organised on different spatial scales, from the local to the global.

What are the lessons for industrial policy? Industrial policy and the strategies of the industrial development agencies in Ireland and Scotland have long included the idea of building integrated vertical production clusters around subsidiaries of MNEs, including computer assembly plants (IPRG, 1992; Turok, 1997). The findings of this research suggest that such strategies are becoming increasingly unsuitable in the context of the microcomputer industry and, probably, in the context of many other industries driven by time-based-competition. In this light, Irish and Scottish policy makers appear to have taken the right course in their decision to move away from actively attracting low value-added manufacturing operations in the second half of the 1990s.

Rising wage rates mean that Ireland and Scotland are no longer able to function as the new semi-periphery of Europe. This role appears to be taken over by a number of Eastern European economies. As a result, Ireland and Scotland's positions as competitive locations for microcomputer assembly operations is most likely to deteriorate. Furthermore, even if some assembly activity remains, this is unlikely to stimulate the development of vertical production clusters. The growing difference in labour costs between Ireland and Scotland and certain countries like China, in combination with innovations and price reductions in transport and logistics, make this increasingly unlikely. A local sourcing route to cluster development might meet more success in industries using components with a high physical volume or weight. The strategy might also be more suitable in industries where partnerships involve higher-order alliances, such as joint $\mathrm{R} \& \mathrm{D}$, characterised by highly intensive technical information exchange.

Both IDA Ireland and Scottish Enterprise are now appropriately focussing on attracting non-assembly functions of the global production networks in the microcomputer industry, in 
particular system development, software development, sales and technical support call centres, e-commerce, shared services and regional headquarter functions. At the same time, however, arguably futile efforts are made to maintain a competitive location for system assembly. The first part of the strategy appears to be bearing fruit. This article focussed on the demise of the hardware manufacturing activity. However, since the mid-1990s companies like, Dell, Apple, IBM, Compaq and Sun have increasingly been adding functions to their local operations, notably sales call centres and higher-end activities such as technical support call centres, shared services and software development. These functions partly offset the losses in manufacturing activity documented in this article.

\section{Acknowledgements}

The research presented in this article was funded by the Irish Research Council for the Humanities and Social Sciences and Forfas. We wish to thank IDA Ireland and Scottish Enterprise for facilitating the research, Nick Phelps for his advice and two anonymous referees for their constructive comments.

\section{Notes}

1. The microcomputer hardware industry is defined as the industry producing personal computers (including laptops and notebooks), workstations and entry-level servers costing less than $\$ 100,000$ in 2001.

2. The 11 microcomputer companies in Ireland and Scotland made extensive use of temporary labour. Temporary workers typically accounted for 20 to 30 per cent of the work force at peak periods.

3. For a detailed account of the activities and employment levels of the focal companies see Van Egeraat (2002) and Van Egeraat et al. (2002).

4. The discrepancy in the two data sets is probably partly explained by the fact that the IEE figures include expenditure on items bought from local turnkey supply-chain-managers but manufactured in other regions as well as expenditure on complete systems manufactured by local contract manufacturers. Both items were excluded in the data collected during the company interviews.

5. Further detail and maps of the regional supply networks of the microcomputer assemblers are provided in Van Egeraat (2002).

6. One company sourced an extremely low part of its material inputs in Scotland, largely due to the fact that the recently established plant was still in the process of forging local linkages.

7. The figures exclude items manufactured by the system assemblers in-house, notably the on-site produced circuit boards of IBM and Digital.

8. Even the regional HQ function of Gateway was split between Dublin and Uxbridge. Sun and Apple had their regional HQs respectively in Scotland and Ireland, but the regional HQs of sales and marketing were located respectively in London and Paris.

\section{References}

Adamson, J. (2001) Interview with former CEO of NCR Scotland, December.

Angel, D. and Engstrom, J. (1995) Manufacturing systems and technological change: The U.S. personal computer industry, Economic Geography, 71(1), pp. 79-102.

BAIN, S. (1997) Europe's largest sub-contractor formed, The Herald, 02-09-1997.

BRADLEY, J. (2001) Industrial strategy and business planning in Ireland. Paper presented at the Economic and Social Research Institute Seminar Series, ESRI, Dublin, 1 November 2001.

Brennan, N. (2001) Logistics and the Spatial Restructuring of the Irish Personal Computer Industry. Unpublished Masters thesis, NUI Maynooth, Maynooth.

Buxton, J. (1987) US electronics group to set up Scottish plant, Financial Times, 24-09-1987.

Garding, T. (1997) Scotland's silicon glen, Global Logistics and Supply Chain Strategies, 1, pp. 4-6. 
CAREY, B. (1996) Lightfooted IDA trims its sails carefully to bring jobs safely to Mulhaddart port, The Sunday Business Post, 15-12-1996.

Casey, C. (1995) Is Silicon Blarney the kiss of life? The Sunday Business Post, 24-12-1995.

GASEY, C. (1997) Who's making it in IT, The Sunday Business Post, 25-05-1997.

Clarke, T. and BEANY, P. (1993) Between autonomy and dependence: corporate strategy, plant status, and local agglomeration in the Scottish electronics industry, Environment and Planning A, 25(2), pp. 213-232.

Clifford, M. (1998) 90 Jobs to go as Acco gives in to Asian competition, The Irish Independent, 08-01-1998.

DEAn, S. (1993) Computer firms promise to create 575 jobs, The Scotsman, 07-04-1993.

Dedrick, J. and Krafmer, K. (2002) Globalization of the Personal Computer Industry: Trends and Implications. Irvine: Centre for Research on Information Technology and Organizations, University of California.

Denholm, E. (2002) Electronics mass pull-out, The Scotsman, 08-08-2002.

DEy, I. (2002a), Electronics firm axes 600 Scottish jobs, The Scotsman, 01-11-2002.

Dey, I. (2002b) Chunghwa axes 600 Scots jobs in move to China, The Scotsman, 01-11-2002.

Dicken, P., Kelly, P., Olds, K. and Yeung, H. (2001) Chains and networks, territories and scales: Towards a relational framework for analysing the global economy, Global Networks, 1, pp. 89-112.

DoherTy, J. (2003) Fears for another 700 Jobs after electronics firm axes workforce, The Scotsman, 07-01-2003.

Dow, J. (2002) Foxteq to axe 90 jobs in Renfrew, The Scotsman, 27-04-2002.

Duncan, G. (1999) George sews seeds of further jobs gloom as clothing factory closes, The Scotsman, 20-01-1999.

Egeraat, G. van (2002) New High Volume Production, Geographical Configuration of Production Networks and Regional Development: The Case of the Microcomputer Industry in Ireland and Scotland. Unpublished Ph.D. thesis, Dublin: Dublin City University.

EgeraAt, C. van, Jacobson, D. and Phelps, N. (2002) New high volume production and the geographical configuration of production networks: A case study of the microcomputer hardware industry in Ireland and Scotland. Paper presented at the Annual Meeting of the Association of American Geographers, Los Angeles, March 2002.

EgeraAt, C. van (2003) The rise and demise of the Irish and Scottish computer hardware industry. Paper presented at the Conference of Irish Geographers, Trinity College Dublin, 2-4 May 2003.

GerefFi, G. and Korzeniewicz M. (Eds) (1994) Commodity Chains and Global Capitalism. Westport: Praeger.

GEREFFI, G. (1999) International trade and industrial upgrading in the apparel commodity chain, Joumal of International Economics, 48, pp. 37-70.

Green, D. (1992) GPT telephone factory to close, Financial Times, 19-12-1992.

HALL, J. (1993) StrathFab bucks the recession, The Herald, 18-03-1993.

Hanna, D. (1984) Electronics and information technology, in L. RYAN (Ed), Irish Industry in the Eighties. Dublin: Confederation of Irish Industries, pp. 163-174.

Henderson, J., Dicken, P., Hess, M., Coe, N. and Yeung, H. (2002) Global production networks and the analysis of economic development, Review of International Political Economy, 9, pp. 436-464.

Hogan, D. (1998a) Apple fails to put figure on job cuts, The Irish Times, 03-07-1998.

Hogan, D. (1998b) Alps to cut Cork jobs, The Irish Times, 26-05-1998.

Houston, T. (1995) Brands with the tight byte, The Herald, 26-01-1995.

Hunter, A. (1993) Motorola pledges £16m deal, The Herald, 30-06-1995.

IBM (1991) Greenock Newes, February 1991.

Industrial Policy Review Group (IPRG) (1992) A Time for Change: Industrial Policy for the 1990s. Dublin: The Stationery Office.

James, S. (1998) Asian crisis blasts through Scotland's Silicon Glen. The Scotsman, 08-07-1998.

KeOGH, E. (2000) Panasonic blames low prices for closure of factory. The Irish Times, 20-02-2002.

KRAEMER, K. and DeDRICK, J. (1998) Globalization and increasing returns: Implications for the U.S. computer industry, Information Systems Research, 9(4), pp. 303-322.

Locate In Scotland (1983) Electronics in Scotland: Industry Profile. Glasgow: LIS-SDA. 
Mackenna, R. (1998) Jobs go as firm takes work back to Taiwan, The Herald, 14-05-1998.

Macsharry, R. and White, P. (2000) The Making of the Celtic Tiger. Cork: Mercier Press.

McGalman, J. (1988) The Electronics Industry in Britain: Coping with Change. London: Routledge.

Murray, A. (2001) Compaq to shed 700 Erskine jobs, The Scotsman, 03-04-2001.

Murray, A. (2002) Sun's ray of light for Scots tech jobs, The Scotsman, 09-07-2002.

O'Kane, P. (1995) Investors won't be disappointed says IDA chief, The Irish Times, 24-05-1995.

O'Kane, P. (1996) Dundalk job fears grow, The Irish Times, 15-05-1996.

O'Malley, E. (1989) Industry and Economic Development: The Challenge for the Latecomer. Dublin: Gill and Macmillan.

Oulton, N. (1993) Labour Productivity and Unit Labour Costs in Manufacturing: Scotland, the UK and 12 Major

Competitors. London: National Institute of Economic and Social Research, research paper No. 35.

REALISED VISION (2003) http://www.realizedvision.com/digital.htm [accessed, 20-02-2003].

RyAn, F. (1996) Review of the Electronics Industry in Ireland (Internal report). Dublin: IDA Ireland.

Schoenberger, E. (1997) The Cultural Crisis of the Firm. Oxford: Blackwell.

Scottish Development Agency (1979) The Electronics Industry in Scotland: a Proposed Strategy. Glasgow: SDA.

Sмyth, J. (2001) 900 jobs lost at Gateway as company closes Dublin base, The Irish Times, 09-08-2001.

Stalk, G. and hout, T. (1990) Competing Against Time: How Time-Based Competition is Reshaping Global Markets. New York and London: The Free Press and Collier Macmillan.

TAYLOR, P. (1998) Jobs to go in AST shake-up, Financial Times, 02-02-1998.

Turnbull, B. (2002) Jobs slashed as Volex plans shake-up, Daily Post (Liverpool), 08-01-2002.

TUROK, I. (1993) Inward investment and local linkages: How deeply embedded is 'Silicon Glen'? Regional Studies, 27(5), pp. 401-417.

TuROK, I. (1997) Linkages in the Scottish electronics industry: Further evidence, Regional Studies, 31(7), pp. 705-711.

Urquhart, C. (1998) Compaq to close plants and Axe 500, The Scotsman, 30-06-1998.

VERNON, R. (1966) International investment and international trade in the product life cycle, Quarterly Fournal of Economics, 80, pp. 190-207.

VERnON, R. (1979) The product cycle hypothesis in a new international environment, Oxford Bulletin of Economics and Statistics, 41, pp. 255-67.

WaLKo, J. (1998) 500 Scot jobs go as Compaq reorganises, Electronics Times, 06-07-1998.

WoOdCOCK, J. (2001) New hi-tech firm hit by job cut fears, The Scotsman, 28-04-2001.

Yeung, H., Dicken, P., Henderson, J., Hess, M. and Coe, N. (2001) Foreign direct investment, trade, and global production networks in Asia and Europe. Paper presented at the 3rd Annual Global Development Conference on Blending Local and Global Knowledge, Sofitel Rio Palace Hotel, Rio de Janeiro, 9-12 December 2001.

Young, A. (2001) Motorola and collateral damage, The Herald, 30-04-2001.

Young, A. (2003) Management manoeuvring has carved out new future for workers in Greenock, The Herald, 08-01-2003. 
Table A1. Major investments in computer component sector Ireland

\begin{tabular}{|c|c|c|}
\hline Molex & 1971 & Cables and interconnect material \\
\hline Dataproducts Corp. & $<1976$ & Printers \\
\hline Memory & & Memory products \\
\hline Southborough. & 1976 & Metal components enclosures \\
\hline Centronics & 1977 & Printers \\
\hline Hormann Electronics & 1977 & Metal components enclosures \\
\hline Verbatim & 1979 & Floppy production \\
\hline Mostek & 1979 & Memory products \\
\hline Applied Magnetics & 1979 & Tape heads \\
\hline Bournes Inc. & 1979 & Connectors \\
\hline DEG (Clonmel) & 1979 & Network connections and power supplies \\
\hline Documentation Inc. & $<1980$ & Printers (taken over by Storage Tech in 1980) \\
\hline Ballymount (I) & 1980 & Metal components enclosures \\
\hline The Keyboard Company & 1981 & Keyboards (plant purchased by Apple in 1982) \\
\hline Data Packaging (I) & 1981 & Plastic components enclosures \\
\hline Western Digital & 1983 & Storage and networking controller cards \\
\hline Key Tronic & 1985 & Keyboards \\
\hline Microsoft & 1985 & Media duplication \\
\hline BG Turnkey (I) & 1986 & $\begin{array}{l}\text { Subcontract and supply-chain services (taken over by } \\
\text { Banta in 1996) }\end{array}$ \\
\hline Cable Products & 1986 & Cable assemblies \\
\hline Apple & 1987 & Motherboards \\
\hline Alps & 1988 & Keyboard production in former Apple \\
\hline Logitech & 1988 & Mice \\
\hline R Donnelley (Modes Media) & 1989 & $\begin{array}{l}\text { Printed material and later media (take-over Irish } \\
\text { Printers) }\end{array}$ \\
\hline Intel & 1990 & Motherboards \\
\hline Mitsui (Mallow) & 1991 & Keyboards \\
\hline Volex & 1992 & Cable assemblies (purchase of Cable Products plant) \\
\hline Cabletron & 1992 & Network cards and other components \\
\hline 3-Com & 1992 & Network products \\
\hline MKIR/Quantum & 1992 & Hard disk drives \\
\hline Dovatron & 1992 & Motherboards \\
\hline Nypro & 1993 & Plastic components for enclosures and subassembly \\
\hline MSL & 1994 & Circuit boards \\
\hline Keytech & 1994 & Cable assemblies \\
\hline Intel & 1994 & Microprocessor wafer fabrication \\
\hline Seagate & 1995 & Hard disc drives \\
\hline Madge Networks & 1995 & Network cards and components \\
\hline CTM & 1997 & Enclosures and subassembly (take-over Southborough) \\
\hline APW & 1997 & $\begin{array}{l}\text { Enclosures, motherboards and subassembly (take-over } \\
\text { G-Fab and later Horman Electronics) }\end{array}$ \\
\hline Intel & 1998 & Pentium cartridge packaging \\
\hline Celestica & 1998 & $\begin{array}{l}\text { Network products (purchase of plant Madge } \\
\text { Networks) }\end{array}$ \\
\hline Trend & 1998 & $\begin{array}{l}\text { Enclosures and subassembly (take-over Datap. and } \\
\text { Ballym.) }\end{array}$ \\
\hline Flextronics & 1998 & Enclosures and subassembly (take-over LMS Beach) \\
\hline Fullarton & 1999 & Enclosures and subassembly \\
\hline Foxteq & 1999 & Enclosures and subassembly \\
\hline Flextronics & 2000 & $\begin{array}{l}\text { Network components, circuit boards and logistics } \\
\text { services (take-over of IEC, Dovatron and purchase of } \\
\text { Cabletron plant) }\end{array}$ \\
\hline Nypro Waterford & 2001 & $\begin{array}{l}\text { Plastic components for enclosures and subassembly } \\
\text { (local presence since 1984) }\end{array}$ \\
\hline
\end{tabular}

Source: Newspaper articles. Details available from authors.

Note: (I) denotes indigenous company. 
Table A2. Closures or major job losses in Irish computer component sector, 1992-2003

\begin{tabular}{|c|c|c|}
\hline Western Digital & 1992 & Closure of automated circuit board facility \\
\hline Logitech & 1995 & End of mouse production activities \\
\hline Keytronics & 1996 & End of keyboard production activities \\
\hline Seagate & 1997 & Closure hard disk drives assembly facility \\
\hline Mitsumi & 1998 & Closure keyboard production facility \\
\hline Alps & 1998 & End of keyboard production activities \\
\hline Acco & 1998 & Closure plastic component facility \\
\hline Apple & 1998 & Closure motherboard assembly facility \\
\hline Intel & 1998 & Closure motherboards and system assembly facility \\
\hline Intel & 1999 & Closure Pentium cartridge assembly facility \\
\hline GTM-Southborough & 1999 & $\begin{array}{l}\text { Job cuts at enclosure production and subassembly } \\
\text { facility }\end{array}$ \\
\hline Quantum & 1999 & Job cuts at tape/ hard disc configuration facility \\
\hline Fullarton & 2000 & $\begin{array}{l}\text { Closure of enclosure production and subassembly } \\
\text { facility }\end{array}$ \\
\hline MKIR & 2000 & Closure of hard disk production facility \\
\hline CTM-Southborough & 2001 & $\begin{array}{l}\text { Job cuts at enclosure production and subassembly } \\
\text { facility }\end{array}$ \\
\hline Volex & 2001 & Job cuts at cable production facility \\
\hline APW (Galway) & 2001 & $\begin{array}{l}\text { Job cuts at enclosure production and subassembly } \\
\text { facility }\end{array}$ \\
\hline SCI & 2001 & Job cuts at printed circuit board facility \\
\hline Modus Media & 2001 & Job cuts at media/kitting facility \\
\hline Industrial print & 2001 & Job cuts at logo manufacturing facility \\
\hline Foxteq & 2001 & Closure enclosure production and subassembly facility \\
\hline Volex & 2002 & Job cuts at cable production facility \\
\hline Flextronics (Tullamore) & 2002 & Closure enclosure production and subassembly facility \\
\hline Flextronics (Limerick) & 2002 & Closure of network component production facility \\
\hline GTM-Southborough & 2002 & Closure enclosure production and subassembly facility \\
\hline Trend Technologies & 2003 & Closure enclosure production and subassembly facility \\
\hline 3Com & 2003 & Closure network products production facility \\
\hline
\end{tabular}

Source: Newspaper articles. Details available from authors. 
Table A3. Major investments in computer component sector Scotland

\begin{tabular}{|c|c|c|}
\hline IBM & $1950 \mathrm{~s}$ & Keyboards \\
\hline AMP & $1950 \mathrm{~s}$ & Cables and connectors \\
\hline IBM & $1970 \mathrm{~s}$ & Monitors and printers \\
\hline Burroughs & $1970 \mathrm{~s}$ & Hard disk drives \\
\hline TFG Cable assemblies (I) & $1970 \mathrm{~s}$ & Cables \\
\hline Strathclyde Fabricators (I) & 1974 & Metal components for enclosures \\
\hline Simclar $(\mathrm{I})$ & 1976 & Cable assembly \\
\hline Prestwick Circuits (I) & 1979 & Circuit boards (partly for IBM) \\
\hline Fullarton (I) & 1980 & $\begin{array}{l}\text { Metal components and later enclosure subassembly } \\
\text { (founded 1978) }\end{array}$ \\
\hline Rodime (I) & 1981 & Hard disk drives \\
\hline Lithgow Electronics (I) & 1981 & Subcon. cable assembly and since ' 89 monitor assembly \\
\hline Seagate Livingston & 1984 & Chips for hard disk drives \\
\hline Digital & 1984 & Circuit boards \\
\hline SGI & 1983 & Circuit boards \\
\hline IBM & 1986 & Circuit boards (expansion) \\
\hline Turnkey (I) & & Subcontract services \\
\hline Brands (I) & 1986 & Subcontract and supply chain management services \\
\hline Avex & 1987 & Circuit boards \\
\hline Eeco & 1988 & Keyboards \\
\hline Domain Power (I) & 1988 & $\begin{array}{l}\text { Power supplies (later taken over Switchcraft and } \\
\text { Minebea) }\end{array}$ \\
\hline Digital & 1988 & Processor packaging line \\
\hline Amphenol & 1989 & Cable assemblies \\
\hline Digital & 1990 & Alpha processor fabrication \\
\hline Conner Peripherals & 1990 & Hard disk drives \\
\hline CTS & 1991 & Computer circuit boards (local presence since 1988) \\
\hline Fife Fabrication (I) & $<1992$ & Metal components and later enclosure subassembly \\
\hline Apricot & 1992 & Circuit boards \\
\hline Sun Microsystems & 1993 & Circuit boards \\
\hline Printech & 1993 & Printed material and supply chain services \\
\hline Jabil Circuit & 1992 & Circuit boards \\
\hline Solectron & 1993 & Circuit boards \\
\hline Compaq & 1994 & Circuit boards \\
\hline Chunghwa & 1995 & Picture tubes \\
\hline Birkbys & 1995 & Plastic components and enclosure subassembly \\
\hline McKechnie & 1995 & Plastic components and enclosure subassembly \\
\hline Bermo & 1996 & Metal components and enclosure subassembly \\
\hline Lite-on & 1996 & Monitors \\
\hline Seagate & 1997 & Hard disc drive configuration \\
\hline Modus Media & 1997 & Media kitting \\
\hline Foxteq & 1998 & Enclosures and subassembly \\
\hline Techdyne & 1998 & Cable assemblies \\
\hline Delta Electronics & 1998 & Power supplies \\
\hline
\end{tabular}

Source: Newspaper articles. Details available from authors.

Note: (I) denotes indigenous company. 


\section{Chris Van Egeraat and David Jacobson}

Table A4. Closures and major job losses in Scottish computer component sector, 1990-2003

\begin{tabular}{|c|c|c|}
\hline Ecco & $<1995$ & Closure keyboard production facility \\
\hline IBM & $<1995$ & Outsourcing monitor and keyboard production \\
\hline Rodime & 1991 & Closure hard disk drive production facility \\
\hline Conner Peripherals & 1993 & Closure hard disk drive production facility \\
\hline Digital Equipment & 1995 & $\begin{array}{l}\text { Sale Alpha processor fabrication plant in Livingston } \\
\text { Closure processor packaging line in Ayr }\end{array}$ \\
\hline Sun Microsystems & 1998 & $\begin{array}{l}\text { Outsourcing circuit board assembly to CEMs in } \\
\text { Scotland and England }\end{array}$ \\
\hline $\begin{array}{l}\text { Clairemont Electronics (formerly } \\
\text { Lithgow Electr.) }\end{array}$ & 1998 & Closure of monitor assembly line \\
\hline Lite-On & 1998 & Closure monitor assembly facility \\
\hline Compaq & 1998 & Shift of motherboard assembly line to Singapore \\
\hline Apricot & 1999 & $\begin{array}{l}\text { Outsourcing motherboard assembly to MSL in } \\
\text { Ireland }\end{array}$ \\
\hline IBM & 1999 & $\begin{array}{l}\text { Outsourcing server board assembly to Solectron } \\
\text { Scotland }\end{array}$ \\
\hline AMP & 1999 & Closure of cable assembly facility \\
\hline Seagate Irvine & 2000 & Closure disk drive configuration facility \\
\hline Amphenol & 2001 & Closure cable assembly facility \\
\hline Solectron & 2001 & Closure of motherboard assembly facility \\
\hline Techdyne & 2001 & Closure of cable assembly facility \\
\hline Sanmina-SCI (Irvine) & 2002 & Closure of circuit board assembly facility \\
\hline Foxteq & 2002 & Closure enclosure production and subassembly facility \\
\hline Chunghwa & 2002 & Closure picture tube production facility \\
\hline
\end{tabular}

Source: Newspaper articles. Details available from authors. 